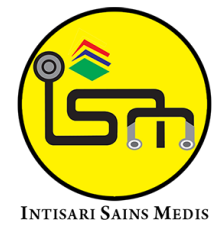

Published by Intisari Sains Medis

\title{
Pencapaian vaksinasi COVID-19 pada anak usia 12-18 tahun periode Agustus - September 2021 di Puskesmas Kelurahan Cililitan
}

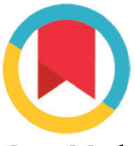

CrossMark

Luh Kadek Shastri Utami Wijayanti ${ }^{*}$, Aan Kurniawan', Amalia Farahtika Srikandi', Jovian Lutfi Daniko', Setya Bayu Kurniawan²

\section{ABSTRACT}

Background: The morbidity and mortality rate of COVID-19 in Indonesia is increasing. Various efforts have been made to prevent the transmission process which is expected to have a significant impact in reducing morbidity and mortality due to COVID-19. One of the steps taken by the Indonesian government is the implementation of COVID-19 vaccination for the entire community. The COVID-19 vaccination program in Indonesia is planned to run from February 2021 to March 2022, where one of the targets for COVID-19 vaccination is children.

Aim: The study was conducted to assess the achievement of COVID-19 vaccination in children aged $12-18$ years at the Cililitan Urban Village Health Center for the period August - September 2021.

Method: This research is a cross-sectional study conducted at the Cililitan Urban Village Health Center in 0ctober 2021. The research sample was all vaccine participants at the Cililitan Urban Village Health Center who attended the first and second vaccines with a total sampling technique. The research data were obtained through documentation of vaccination records at the
Cililitan Urban Village Health Center. The data obtained are presented as part of personal data and vaccination achievements in graphic form.

Result: The recording of the results of vaccination services is carried out electronically through the information system for one COVID-19 vaccination data, namely the Pcare application which is carried out during the COVID-19 vaccination service. The COVID-19 vaccination program for children aged 1218 years has been implemented since July 1, 2021. The Cililitan Urban Village Health Center area has 16 Neighborhood Units with a total population of children aged 12-18 years as many as 2955 people. The results of the achievements of children aged 12-18 years in the Cililitan Urban Village area for the period August - September 2021 who were vaccinated with the first dose were $13.73 \%$ and the second dose vaccinated was $24.53 \%$.

Conclusion: The Cililitan Urban Village Health Center has run a vaccination program for children aged 1218 years, but the vaccination coverage in AugustSeptember 2021 has not reached the target of $50 \%$.

Keywords: children, coverage, vaccination, COVID-19.

Cite This Article: Wijayanti, L.K.S.U., Kurniawan, A., Srikandi, A.F., Daniko, J..., Kurniawan, S.B. 2021. Pencapaian vaksinasi COVID-19 pada anak usia 12-18 tahun periode Agustus - September 2021 di Puskesmas Kelurahan Cililitan. Intisari Sains Medis 12(3): 981-985. D0I: 10.15562/ism.v12i3.1210

'Dokter Internsip Puskesmas Kelurahan Cililitan, Jakarta Timur, Indonesia;

${ }^{2}$ Dokter Pendamping Internsip Puskesmas Kelurahan Cililtan, Jakarta Timur, Indonesia;

\section{*Korespondensi:}

Luh Kadek Shastri Utami Wijayanti;

Dokter Internsip Puskesmas Kelurahan Cililitan, Jakarta Timur, Indonesia;

shastriutami@gmail.com

Diterima: 04-10-2021

Disetujui: 09-12-2021

Diterbitkan: 30-12-2021

\section{ABSTRAK}

Latar Belakang: Angka kesakitan dan kematian COVID-19 di Indonesia semakin meningkat. Berbagai upaya dilakukan untuk mencegah proses penularan yang diharapkan berdampak signifikan dalam menurunkan angka kesakitan dan kematian akibat penyakit COVID-19. Salah satu langkah yang diambil dari pemerintah Indonesia yaitu pelaksanaan vaksinasi COVID-19 untuk seluruh masyarakat. Program vaksinasi COVID-19 di Indonesia direncanakan berlangsung dari bulan Februari 2021 hingga Maret 2022, dimana salah satu sasaran vaksinasi COVID-19 adalah anak - anak. Tujuan: Penelitian dilaksanakan untuk melakukan penilaian terhadap pencapaian vaksinasi COVID-19 pada anak usia 12 - 18 tahun di Puskesmas Kelurahan Cililitan periode Agustus - September 2021.

Metode: Penelitian ini merupakan studi potong lintang yang dilaksanakan di Puskesmas Kelurahan Cililitan pada bulan Oktober 2021. Sampel penelitian adalah semua peserta vaksin Puskesmas Kelurahan Cililitan yang hadir vaksin pertama dan kedua dengan teknik total sampling. Data penelitian didapatkan melalui dokumen pencatatan vaksinasi di Puskesmas Kelurahan Cililitan. Data yang diperoleh disajikan menjadi bagian data diri dan capaian vaksinasi dalam 
bentuk grafik.

Hasil: Pencatatan hasil pelayanan vaksinasi dilakukan secara elektronik melalui sistem informasi satu data vaksinasi COVID-19, yaitu aplikasi Pcare yang dilakukan saat pelayanan vaksinasi COVID-19 berlangsung. Program vaksinasi COVID-19 untuk anak usia 12 - 18 tahun sudah dilaksanakan sejak 1 Juli 2021. Wilayah puskesmas memiliki 16 Rukun Warga dengan total populasi anak usia 12 - 18 tahun sebanyak 2955

Kata kunci: anak, capaian, vaksinasi, COVID-19.

Sitasi Artikel ini: Wijayanti, L.K.S.U., Kurniawan, A., Srikandi, A.F., Daniko, J.L., Kurniawan, S.B. 2021. Pencapaian vaksinasi COVID-19 pada anak usia 12-18 tahun periode Agustus - September 2021 di Puskesmas Kelurahan Cililitan. Intisari Sains Medis 12(3): 981-985. D0I: 10.15562/ism.v12i3.1210 orang. Hasil capaian anak usia $12-18$ tahun di wilayah Kelurahan Cililitan periode Agustus - September 2021 yang tervaksinasi dosis I sebesar 13,73\% dan tervaksinasi dosis II sebesar 24,53\%.

Kesimpulan: Puskesmas Kelurahan Cililitan telah menjalankan program vaksinasi anak usia $12-18$ tahun, namun cakupan vaksinasi pada bulan Agustus September 2021 belum mencapai target hingga 50\%.

\section{LATAR BELAKANG}

COVID-19 merupakan penyakit infeksi yang disebabkan oleh virus SARS-CoV2 yang saat ini sedang marak terjadi di seluruh dunia, tidak terkecuali Indonesia. Infeksi saluran pernapasan menjadi salah satu kondisi yang lazim ditemukan pada pasien yang terinfeksi oleh virus ini. Bermula dari Kota Wuhan, Hubei, China pada bulan Desember 2020, infeksi ini terus menyebar ke seluruh dunia. Sudah 12 bulan, COVID-19 ditetapkan oleh World Health Organization (WHO) sebagai kedaruratan kesehatan masyarakat yang meresahkan dunia, yang saat ini lebih dikenal dengan istilah pandemi. ${ }^{1}$

Angka kesakitan dan kematian COVID-19 di Indonesia semakin meningkat. Menurut data 11 Maret 2021, jumlah temuan kasus baru COVID-19 di Indonesia mencapai angka 5.144 kasus baru. Angka kasus aktif di DKI Jakarta mencapai 7.620 kasus dan angka kematian mencapai 5.943 kasus. $^{2}$

Berbagai upaya dilakukan untuk mencegah proses penularan yang diharapkan berdampak signifikan dalam menurunkan angka kesakitan dan kematian akibat penyakit COVID-19. Disamping promosi Kesehatan seperti upaya gerakan $3 \mathrm{M}$ yaitu mencuci tangan, memakai masker, dan menjaga jarak, pemberian vaksinasi COVID-19 diharapkan menjadi salah satu upaya yang efektif dalam menurunkan angka penularannya. ${ }^{3}$

Presiden Republik Indonesia telah menetapkan per tanggal 6 Oktober 2020, Peraturan Presiden tentang pengadaan vaksin dan pelaksanaan program vaksinasi untuk menanggulangi pandemi COVID-19. Perpres tersebut menetapkan bahwa pemerintah akan mempersiapkan pengadaan dan distribusi vaksin serta pelaksanaan vaksinasi di Indonesia. Disamping itu, Kementerian Kesehatan dan United Nations Children's Fund (UNICEF) telah menandatangani nota kesepahaman (MoU) dalam memastikan vaksin tersedia dengan harga terjangkau. Dengan kesepakatan tersebut secara tidak langsung, lembaga kesehatan internasional dalam hal ini adalah WHO akan menjamin kelancaran dan pengadaan vaksin COVID-19 di Indonesia. ${ }^{3}$

Program vaksinasi COVID-19 di Indonesia direncanakan berlangsung dari bulan Februari 2021 hingga Maret 2022, tersusun dalam empat tahap. Tahap kedua berlangsung dari Bulan Januari 2021 hingga Bulan April 2021. Target sasaran vaksinasi pada tahap ini adalah kelompok lansia dan petugas pelayanan publik (TNI, Kepolisian, Aparat publik lain). ${ }^{4}$ Kegiatan vaksinasi pada kelompok anak - anak dimulai dari bulan Juli 2021 hingga saat ini di Puskesmas Kecamatan karena pertimbangan kesediaan miniICU. Setelah berlangsung beberapa hari, dengan melihat keadaan pasien setelah divaksin terlihat aman, selanjutnya vaksinasi COVID-19 anak ini dapat dilaksanakan di Puskesmas Kelurahan.

Berdasarkan uraian di atas, penulis tertarik untuk melakukan penilaian terhadap pencapaian vaksinasi COVID-19 pada anak usia 12 - 18 tahun di Puskesmas Kelurahan Cililitan periode Agustus -
September 2021.

\section{METODE}

Penelitian ini merupakan studi potong lintang yang dilaksanakan di Puskesmas Kelurahan Cililitan pada bulan Oktober 2021. Populasi kegiatan ini adalah peserta anak usia 12 - 18 tahun vaksinasi dosis 1 dan 2 dengan vaksin Sinovac. Sampel penelitian adalah semua peserta vaksin Puskesmas Kelurahan Cililitan yang hadir vaksin pertama dan kedua dengan teknik total sampling. Kriteria inklusi penelitian ini adalah semua peserta vaksinasi anak usia 12 - 18 tahun di kelurahan Cililitan pada bulan Agustus - September 2021. Kriteria eksklusi adalah peserta vaksinasi diatas 18 tahun. Data penelitian ini merupakan data sekunder yang didapatkan melalui dokumen pencatatan vaksinasi di Puskesmas Kelurahan Cililitan. Data yang diperoleh melalui dokumen yang tersedia lalu disunting, dan ditabulasi. Bagian data diri dan capaian vaksinasi akan disajikan distribusi data dalam bentuk grafik.

\section{HASIL}

\section{Proses pelaksanaan vaksinasi COVID-19 pada anak usia 12 - 18 tahun di Kelurahan Cililitan}

Pelaksanaan vaksinasi telah dilakukan pencatatan dan pelaporan. Pencatatan hasil pelayanan vaksinasi dilakukan secara elektronik melalui sistem informasi satu data vaksinasi COVID-19, yaitu aplikasi Pcare yang dilakukan saat pelayanan vaksinasi COVID-19 berlangsung. Selain Pcare, pencatatan hasil pelayanan juga 
Tabel 1. Susunan meja dalam alur pelayanan vaksinasi COVID-19.

Urutan Meja

Meja 2

Meja 3

\section{Keterangan}

1. Anamnesis dilakukan oleh petugas kesehatan untuk meninjau kondisi kesehatan melaui pemeriksaan fisik sederhana meliputi suhu tubuh dan tekanan darah. Petugas Kesehatan juga akan mengidentifikasi kondisi penyerta (komorbid).

2. Dilanjutkan dengan pengisian keputusan hasil skrining oleh petugas pada formulir kartu kendali vaksinasi; a) Ketika pada saat skrining dideteksi ada penyakit tidak menular atau dicurigai adanya infeksi COVID-19 sesuai dengan pedoman Perhimpunan Dokter Spesialis Penyakit Dalam Indonesia (PAPDI), maka pasien dirujukke poli umum untuk mendapat pemeriksaan lebih lanjut atau ditunda, b) Sasaran yang dinyatakan sehat diminta untuk melanjutkan ke meja 2.

1. Petugas memberikan vaksinasi secara intramuskular sesuai prinsip penyuntikan aman.

2. Vaksin yang digunakan adalah vaksin Sinovac.

3. Nama sasaran, NIK, nama vaksin dan nomor batch vaksin dituliskan pada sebuah kartu vaksin dan formulir kartu kendali. Kartu kendali diberikan kepada sasaran untuk diserahkan ke petugas di meja 3.

1. Petugas melakukan observasi peserta vaksin selama 15 menit pasca suntikan di ruang observasi.

2. Petugas memberikan kartu vaksinasi kepada sasaran yang telah mendapat vaksinasi setelah observasi selesai serta menginformasikan tanggal vaksinasi untuk dosis kedua yang berselang 28 hari dari dosis pertama dimasukkan ke dalam spreadsheet yang sudah dibuat. Saat peserta vaksinasi datang ke tempat pelayanan vaksinasi, peserta membawa data diri berupa fotokopi kartu keluarga atau kartu tanda penduduk (KTP) jika sudah memasuki usia 17 tahun ke atas. Selanjutnya peserta mengisi data diri pada formulir kartu kendali. Ketentuan alur pelayanan vaksinasi COVID-19 ini dibagi menjadi tiga susunan meja (Tabel 1).

\section{Populasi anak usia 12-18 tahun di Kelurahan Cililitan}

Program vaksinasi COVID-19 untuk kelompok anak usia 12 - 18 tahun sudah mulai dikerahkan di wilayah kelurahan Cililitan pada 1 Juli 2021. Wilayah ini memiliki 16 Rukun Warga (RW). Menurut data dari Kantor Kelurahan Cililitan tahun 2021 total populasi anak dan remaja usia 12 - 18 tahun sebanyak 2955 orang.

Capaian vaksinasi COVID-19 pada anak usia 12-18 tahun di Kelurahan Cililitan

Program vaksinasi anak usia 12 - 18 tahun ini dilaksanakan setiap hari SeninJumat di Puskesmas Kelurahan Cililitan dan di RW setempat secara bergantian. Kegiatan dilaksanakan dengan tetap memperhatikan protokol COVID-19 yaitu, dengan memakai masker, menjaga jarak minimal 1 meter dan disediakan tempat untuk mencuci tangan. ${ }^{5}$ Peserta dapat datang langsung ke tempat dimana vaksinasi diadakan baik itu di Puskesmas Kelurahan Cililitan atau di RW terdekat.

\section{Capaian Vaksinasi COVID-19 Dosis I pada Anak Usia 12- 18 tahun di Kelurahan Cililitan}

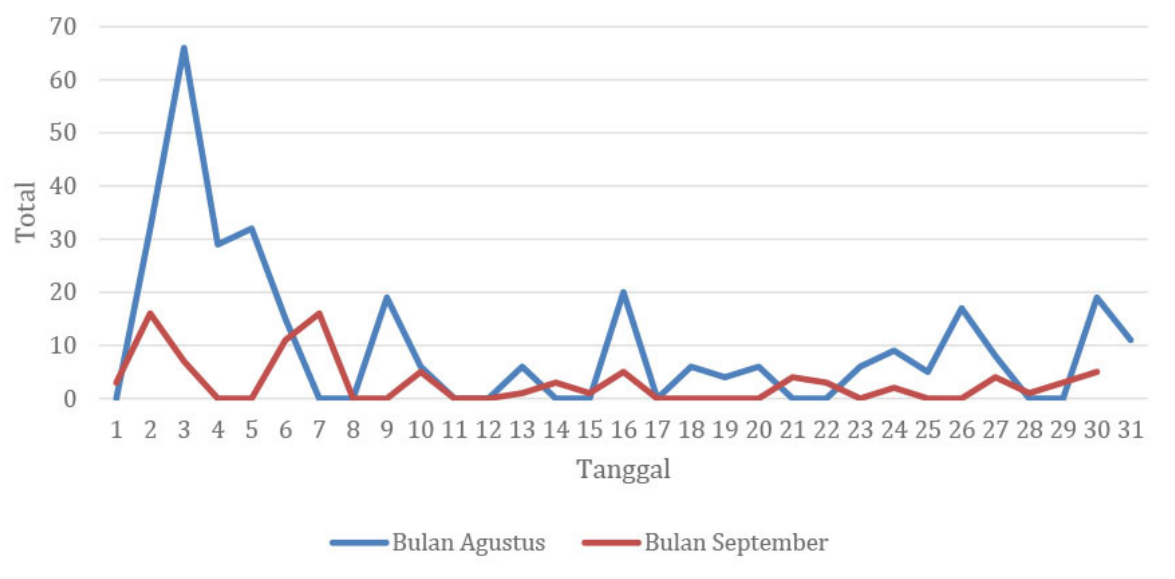

Gambar 1. Capaian vaksinasi COVID-19 dosis I pada anak usia 12 - 18 tahun di Kelurahan Cililitan.

Hasil capaian anak usia 12 - 18 tahun di wilayah Kelurahan Cililitan yang tervaksinasi dosis 1 periode Agustus September 2021 didapatkan sebanyak 406 dari total populasi 2955 remaja (Gambar 1). Persentase anak usia 12 - 18 tahun yang tervaksinasi bulan Agustus - September sebesar $13,73 \%$.

Hasil capaian anak usia 12 - 18 tahun di wilayah Kelurahan Cililitan yang tervaksinasi dosis 2 periode Agustus September 2021 didapatkan sebanyak 725 dari total populasi 2955 remaja (Gambar 2). Persentase remaja yang tervaksinasi bulan Agustus-September sebesar 24,53\%.

\section{DISKUSI}

Imunisasi adalah upaya pembentukan kekebalan tubuh seseorang terhadap suatu penyakit, sehingga apabila suatu saat terkena penyakit yang sama tidak akan sakit atau hanya timbul sakit ringan. Imunisasi didapatkan baik secara alami maupun buatan. Bentuk proses imunisasi alami ditemukan pada kondisi infeksi alami, sedangkan bentuk proses imunisasi buatan ditemukan pada kondisi vaksinasi. ${ }^{4}$ Vaksinasi merupakan salah satu bentuk imunisasi yang didapatkan secara buatan, dengan cara menyuntikan antigen agen penyebab suatu penyakit ke dalam tubuh sehingga tubuh dapat membentuk sistem 


\section{Capaian Vaksinasi COVID-19 Dosis II pada Anak Usia 12-} 18 tahun di Kelurahan Cililitan

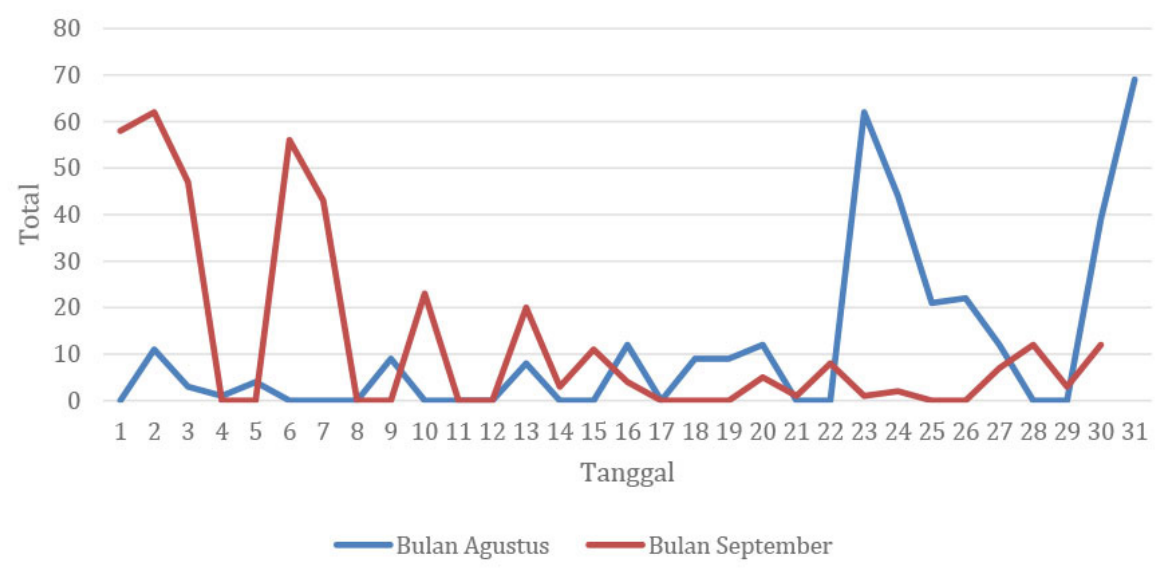

Gambar 2. Capaian vaksinasi COVID-19 dosis I pada anak usia 12 - 18 tahun di Kelurahan Cililitan.

kekebalan. Zat antigen yang disuntikkan ke dalam tubuh dikenal dengan istilah vaksin. ${ }^{4}$

Virus SARS-CoV-2 merupakan pathogen dari COVID-19 yang tergolong genus Betacoronavirus. Seperti virus genus Betacoronavirus lain, SARS-CoV-2 menyandi empat protein struktur utama, yaitu spike (S) protein, small envelope protein, matrix protein, dan nucleocapsid protein. S protein merupakan protein yang akan berinteraksi dengan reseptor ACE2 dalam tubuh manusia sehingga dapat terjadi replikasi virus melalui ikatan tersebut. Mekanisme tersebut yang menjadi dasar pembuatan vaksin mRNA COVID-19, dimana mengandung mRNA yang menyandi $S$ protein sehingga dapat terbentuk sistem imun adaptif terhadap SARS-CoV-2. Vaksin mRNA dapat berupa vaksin mRNA konvensional berisi mRNA yang serupa dengan molekul mRNA sel induk maupun vaksin mRNA self-amplifying berisi mRNA yang telah direkayasa. ${ }^{6-9}$

Secara umum, tujuan vaksinasi adalah untuk mengurangi proses penularan penyakit infeksi, menurunkan angka kesakitan dan kematian akibat penyakit infeksi, serta mempertahankan produktivitas individu yang terinfeksi. ${ }^{4}$ Kekebalan komunitas merupakan kondisi kekebalan yang terbentuk dalam suatu populasi jika 75 persen populasi sudah dilakukan vaksinasi, sehingga secara tidak langsung individu yang belum divaksin dalam populasi tersebut akan kebal. ${ }^{4}$ Sama seperti obat, vaksin yang dimasukan kedalam tubuh memberikan suatu respon positif dan dapat pula memberikan respon negatif. Respon positif yang diharapkan adalah terbentuknya kekebalan tubuh untuk suatu penyakit, sedangkan respon negatifnya adalah timbulnya efek samping dari vaksin. Efek samping vaksin termasuk kedalam kondisi yang disebut dengan Kejadian Ikutan Pasca Imunisasi (KIPI). ${ }^{4}$

Kejadian Ikutan Pasca Imunisasi (KIPI) merupakan semua kejadian medik yang terjadi 28 hari setelah vaksinasi, bisa berhubungan atau tidak berhubungan dengan vaksin. Reaksi ini digolongkan menjadi reaksi lokal dan reaksi sistemik. Reaksi lokal merupakan reaksi yang timbul di tempat dilakukan penyuntikan vaksin seperti kemerahan, nyeri di tempat suntikan, dan bengkak. Reaksi sistemik merupakan reaksi yang dirasakan secara umum oleh tubuh seperti nyeri kepala, demam, nyeri otot, dan lemas. ${ }^{4}$

Bentuk reaksi KIPI berat disebut dengan reaksi anafilaksis. Reaksi ini timbul sebagai respon alergi tubuh terhadap zat vaksin yang disuntikkan, namun gejala yang ditimbulkan bersifat berat dan mendadak. Reaksi ini bersifat fatal yang tepat dapat menyebabkan kematian. Insidensi reaksi anafilaksis pada vaksin COVID-19 seperti Sinovac dan Pfizer, bahkan jika tidak dilakukan penanganan memiliki probabilitas $<1$ persen. ${ }^{4}$

Vaksinasi COVID -19 bagi anak usia 12-18 tahun dengan menggunakan vaksin Sinovac dan pelaksanaan vaksinasi dilakukan di fasilitas pelayanan kesehatan dan atau di pos pelayanan vaksinasi COVID-19. Pos pelayanan vaksinasi COVID19 dapat didirikan di sekolah/ madrasah/pesantren. ${ }^{4}$ Pembahasan yang disorot terutama adalah vaksinasi anak usia 12-18 karena walaupun infeksi virus COVID-19 termasuk sedikit pada populasi tersebut, tetap saja mereka dapat terinfeksi sehingga Centers for Disease Control and Prevention (CDC) merekomendasikan anak usia 12 - 18 tahun untuk medapatkan vaksin COVID-19. Bagaimanapun juga vaksin merupakan salah satu kunci utama dalam pemberantasan pandemi COVID-19. ${ }^{10}$

Menanggapi kesenjangan hasil capaian penerima vaksinasi anak usia $12-18$ tahun, solusi yang dapat dilakukan selain menyelenggarakan vaksinasi pada RW setempat adalah memberikan edukasi bagi masyarakat khususnya anak usia 12-18 tahun dalam pentingnya vaksinasi COVID-19, serta mengkoordinasikan dengan kader setempat agar lebih gencar mengajak anak dan remaja untuk melakukan vaksinasi COVID-19.

\section{KESIMPULAN}

Puskesmas Kelurahan Cililitan menjalankan program vaksinasi anak dan remaja untuk meningkatkan cakupan di wilayah Kecamatan Kramat Jati. Hasil temuan berdasarkan data yang diperoleh untuk cakupan penerima vaksinasi anak dan remaja untuk wilayah Kelurahan Cililitan pada bulan Agustus - September 2021 masih belum mencapai target hingga $50 \%$.

\section{UCAPAN TERIMA KASIH}

Penulis mengucapkan terimakasih kepada seluruh pihak yang telah membantu penulisan penelitian ini, terutama Puskesmas Kelurahan Cililitan, Jakarta atas kesempatan dan bimbingan yang telah diberikan.

\section{KONFLIK KEPENTINGAN}

Penulis menyatakan tidak terdapat konflik kepentingan dalam melaksanakan dan 
mempublikasi penelitian ini.

\section{PERNYATAAN ETIK}

Penelitian ini telah mendapatkan persetujuan dari manajemen Puskesmas Kelurahan Cililitan.

\section{KONTRIBUSI PENULIS}

LKSUW, AK, AFS, dan JLD berkontribusi secara merata dalam merencanakan rancangan penelitian, melaksanakan penelitian, mengolah data, dan menyusun publikasi. SBK berkontribusi dalam mendampingi dan memberikan saransaran masukan terhadap pelaksanaan dan publikasi penelitian.

\section{REFERENCE}

1. Setiati S, Azwar MK. COVID-19 and Indonesia. Acta Med Indones. 2020;52(1):84-9.
2. COVID-19 Map - Johns Hopkins Coronavirus Resource Center [Internet]. Available from: https://coronavirus.jhu.edu/map.html

3. World Health Organization Indonesia. Survey Penerimaan Vaksin COVID-19 di Indonesia. Kementerian Kesehatan Republik Indonesia, editor. Jakarta; 2020.

4. Komite Penanggulangan COVID-19 dan Pemulihan Ekonomi Nasional. Buku Saku \#infovaksin. Komite Penanggulangan COVID-19 dan Pemulihan Ekonomi Nasional, editor. Jakarta; 2020.

5. Satuan Tugas Penanganan COVID-19. Vaksinasi COVID-19 [Internet]. 2021. Available from: https://covid19.go.id/vaksin-covid19

6. Zhang C, Maruggi G, Shan H, Li J. Advances in mRNA Vaccines for Infectious Diseases. Front Immunol. 2019;10:594. Available from: https:// pubmed.ncbi.nlm.nih.gov/30972078

7. Wang F, Kream RM, Stefano GB. An Evidence Based Perspective on mRNA-SARS-CoV-2 Vaccine Development. Med Sci Monit. 2020;26:e924700-e924700. Available from: https://pubmed.ncbi.nlm.nih.gov/32366816
8. Meet the mRNA vaccine rookies aiming to take down COVID-19 | CAS [Internet]. Available from: https://www.cas.org/resource/blog/ covid-mrna-vaccine

9. Wadhwa A, Aljabbari A, Lokras A, Foged C, Thakur A. Opportunities and Challenges in the Delivery of mRNA-based Vaccines. Pharmaceutics. 2020;12(2):102. Available from: https://pubmed.ncbi.nlm.nih.gov/32013049

10. COVID-19 Vaccines for Children and Teens | CDC [Internet]. Available from: https://www. cdc.gov/coronavirus/2019-ncov/vaccines/ recommendations/children-teens.html?CDC_ AA_refVal=https $\% 3 \mathrm{~A} \% 2 \mathrm{~F} \% 2 \mathrm{Fwww} . \mathrm{cdc}$. gov\%2Fcoronavirus\%2F2019-ncov\%2Fvaccine s\%2Frecommendations\%2Fadolescents.html

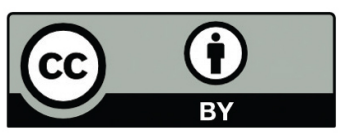

This work is licensed under a Creative Commons Attribution 